\section{In-row Distance in Triploid Miniwatermelon Cultivars Affects Yield and Quality in Diverse Environments in the Southeastern United States}

\author{
Richard L. Hassell ${ }^{1,6}$, Jonathan R. Schultheis ${ }^{2}$, Wilfred R. Jester ${ }^{3}$, \\ Stephen M. Olson ${ }^{4}$, and Gilbert A. Miller ${ }^{5}$
}

AdDitional index wORDs. Citrullus lanatus, seedless watermelon, location effect, genetic expression, population, plant density

SumMary. The goals of these studies were to determine how miniwatermelon (Citrullus lanatus) cultivars differed and responded to plant in-row spacing in terms of percentage of marketable fruit and yields, and if plant spacing impacted internal fruit quality. Three genetically diverse triploid miniwatermelon cultivars (Mohican, Petite Perfection, and Xite) were selected. These cultivars were evaluated in field locations at northern Florida (Quincy), central South Carolina (Blackville), coastal South Carolina (Charleston), and eastern North Carolina (Kinston) at five within-row distances. Within-row distance included 9, 12, 15, 18, and 21 inches. All plots were $15 \mathrm{ft}$ long with row middles $9 \mathrm{ft}$ apart. Fruit were categorized as marketable if they weighed between 3.1 and $9.0 \mathrm{lb}$ per fruit. Within this range further categories were divided as follows: $\leq 3.0 \mathrm{lb}$ (cull), 3.1 to $5.0 \mathrm{lb}$ (small), 5.1 to $7.0 \mathrm{lb}$ (average), 7.1 to $9.0 \mathrm{lb}$ (large), and $\geq 9.1 \mathrm{lb}$ (cull). There was a cultivar by location interaction, suggesting that the three cultivars responded differently at each of the four locations. 'Petite Perfection' was among the highest yielding at all locations except Quincy, where it was the lowest yielding cultivar. As with total yields, the percentage of marketable fruit was similar for some cultivars across locations. Cultivar Petite Perfection produced the highest percentage of marketable fruit at three of the four locations. The exception was the Quincy site where 'Xite' had the highest percentage of marketable fruit. Within-row plant distances and populations affected total marketable yield, both for fruit weight and number per plant, regardless of cultivar and location. As the plant population increased from eight plants per plot (21-inch in-row spacing) to 12 plants per plot ( 15 -inch in-row spacing), total marketable miniwatermelon fruit yields increased in total fruit number as well as total weight. There was a cultivar by location interaction for the percentage of soluble solids and the rind thickness measurements, suggesting that some cultivars responded differently at each of the four locations. Quality effects were more apparent with 'Mohican' and 'Xite', as they were more responsive to location than 'Petite Perfection'.

$\mathrm{P}$ lant population density and its effects on crop yield and quality have been studied on numerous vegetable crops during the past 30 years [e.g., pickling cucumber (Cucumis sativus) (Cantliffe and Phatak, 1975), zucchini (Cucurbita

${ }^{1}$ Clemson University, Coastal Research and Education Center, 2700 Savannah Highway, Charleston, SC 29414

${ }^{2}$ North Carolina State University, Department of Horticultural Science, 264 Kilgore, Box 7609, Raleigh, NC 27695

${ }^{3}$ North Carolina State University, Department of Horticultural Science, Cunningham Research Station, 202 Cunningham Road, Kinston, NC 28501

${ }^{4}$ University of Florida, North Florida Research and Education Center, Quincy, FL 32351

${ }^{5}$ Clemson University, Edisto Research and Education Center, Blackville, SC 29817

${ }^{6}$ Corresponding author. E-mail: rhassel@clemson. edu. реро) (Dweikat and Kostewicz, 1989), muskmelon (Cucumis melo) (Knavel, 1991), pepper (Capsicum annuum) (Stoffella and Bryan, 1988), tomato (Solanum lycopersicum) (Stoffella et al., 1988), snap bean (Phaseolus vulgaris) (Stang et al., 1979), and sweetpotato (Ipomoea batatas) (Schultheis et al., 1999), etc.]. Specifically, plant population density of watermelon has been the focus of many research studies (Brinen et al., 1979; Duthie et al., 1999a, 1999b; Halsey, 1959; NeSmith, 1993; Sanders et al., 1999; Srinivas et al., 1989). However, none of the watermelon studies have addressed the effects of plant population or in-row spacing on miniwatermelons. The introduction of miniwatermelons is recent (Hassell et al., 2007), therefore, information regarding production is scant or lacking. The size requirements for miniwatermelons are specific as most markets require fruit that range between 3 and $8 \mathrm{lb}$, with the 4- to 5-lb size preferred. Generally, increased plant population densities improve yields until a threshold density is reached for a species, at which time yields level off or decline (Weiner, 1990; Willey and Heath, 1969). This has been found to be the case in most studies with watermelon that involved large-fruited cultivars. Except in one instance, marketable yield increased about 30\% when plant (in-row) spacing was decreased from 7.2 to $3.0 \mathrm{ft}$ with 'Crimson Sweet' and 'Starbrite' watermelon (NeSmith, 1993). Highest marketable yields for 'Prince Charles' and 'Royal Jubilee' (greater than or equal to $9.9 \mathrm{~kg} /$ melon) were obtained when polyethylene mulch was used and areas per plant ranged from 4.3 to $9.7 \mathrm{ft}^{2}$ (Sanders et al., 1999). Halsey (1959) reported yield increases when area per plant was reduced from 121.6 to $30.1 \mathrm{ft}^{2}$, while Srinivas et al. (1989) determined that yields were increased when area was

\begin{tabular}{lllc}
\hline $\begin{array}{l}\text { Units } \\
\begin{array}{l}\text { To convert U.S. to SI, } \\
\text { multiply by }\end{array}\end{array}$ & U.S. unit & SI unit & $\begin{array}{l}\text { To convert SI to U.S., } \\
\text { multiply by }\end{array}$ \\
\hline 0.4047 & $\mathrm{acre}(\mathrm{s})$ & $\mathrm{ha}$ & 2.4711 \\
0.3048 & $\mathrm{ft}$ & $\mathrm{m}$ & 3.2808 \\
0.0929 & $\mathrm{ft}^{2}$ & $\mathrm{~m}^{2}$ & 10.7639 \\
3.7854 & $\mathrm{gal}$ & $\mathrm{L}$ & 0.2642 \\
0.1242 & $\mathrm{gal} / \mathrm{l} 00 \mathrm{ft}$ & $\mathrm{L} \cdot \mathrm{m}^{-1}$ & 8.0520 \\
2.54 & inch $(\mathrm{es})$ & $\mathrm{cm}$ & 0.3937 \\
0.4536 & $\mathrm{lb}$ & $\mathrm{kg}$ & 2.2046 \\
0.0015 & $\mathrm{lb} / 1000 \mathrm{ft}$ & $\mathrm{kg} \cdot \mathrm{m}^{-1}$ & 671.9658 \\
1.1209 & $\mathrm{lb} / \mathrm{acre}$ & $\mathrm{kg} \cdot \mathrm{ha}^{-1}$ & 0.8922 \\
0.0254 & $\mathrm{mil}$ & $\mathrm{mm}$ & 39.3701 \\
28.3495 & $\mathrm{Oz}$ & $\mathrm{g}$ & 0.0353 \\
1.1692 & $\mathrm{pt} / \mathrm{acre}$ & $\mathrm{L} \cdot \mathrm{ha}^{-1}$ & 0.8553 \\
$\left({ }^{\circ} \mathrm{F}-32\right) \div 1.8$ & ${ }^{\circ} \mathrm{F}$ & ${ }^{\circ} \mathrm{C}$ & $\left(1.8 \times{ }^{\circ} \mathrm{C}\right)+32$
\end{tabular}


reduced from 9.7 to $6.5 \mathrm{ft}^{2}$. Duthie et al. (1999a) suggested that fruit size decreases more rapidly in cultivars with large fruit than small fruit. Slight variations in miniwatermelon size can result in fruit not being marketable because fruit $1 \mathrm{lb}$ too large will not fit into some packing boxes specifically developed for miniwatermelons. Thus, if fruit production increases with increased plant populations, it is critical that fruit size remain within marketable size constraints so that increased profits may be realized with increasing plant populations.

The goals of these studies were to determine how the cultivars differed and responded to the various plant in-row spacing in terms of percentage of marketable fruit and yields, and if plant spacing impacted internal fruit quality.

\section{Materials and methods}

All locations. Three genetically diverse triploid miniwatermelon cultivars (Mohican, Petite Perfection, and Xite) were selected (Table 1 ). In 2004, these cultivars were evaluated in field locations at northern Florida (Quincy), central South Carolina (Blackville), coastal South Carolina (Charleston), and eastern North Carolina (Kinston). Five within-row spacing, which included 9, 12, 15, 18 , and 21 inches, were evaluated at each location. All plots were $15 \mathrm{ft}$ long with row middles $9 \mathrm{ft}$ apart (Table 1 ). Three pollenizer plants of SP-1 (Syngenta Seed, Boise, ID) were placed in plots, one in the middle, the other two plantsl0 inches away from each plot. Standard cultural practices, specific to the location, were used during the growing season (Olson and Simonne, 2004; Sanders, 2004). Four replications of each treatment were included at each of the locations.

Yield data were grouped by harvests; however, only cumulative harvest yields are presented. Fruit at each site were harvested when watermelons in several plots were at market maturity. Each fruit was weighed, and the total number was recorded. Fruit were categorized as marketable if they weighed between 3.0 and 9.0 $\mathrm{lb}$ per fruit. Within this range further categories were established as follows: $\leq 3.0 \mathrm{lb}$ (cull), 3.1 to $5.0 \mathrm{lb}$ (small), 5.1 to $7.0 \mathrm{lb}$ (average), 7.1 to $9.0 \mathrm{lb}$ (large), and $\geq 9.1 \mathrm{lb}$ (cull). These categories were determined based upon discussions with seed company representatives, participating scientists, and current marketing practices used to sell miniwatermelons. The upper size limit for marketable miniwatermelon fruit $(7.1-9.0 \mathrm{lb})$ is $2 \mathrm{lb}$ greater than fruit considered marketable by Dulcinea Farms (Barboza, 2003); however, other seed companies that market miniwatermelon cultivars suggested that this category should be considered a marketable miniwatermelon. Average fruit size was determined for each cultivar. The number of harvests varied depended on location.

Quality measurements were taken on five randomly selected marketable miniwatermelon fruit from each replication. Each miniwatermelon fruit was cut from stem end to blossom end before quality data were taken. A fresh sample was obtained from the center of the mesocarp of

Table 1. Seed sources and fruit descriptions of triploid miniwatermelon cultivars evaluated in 2004 at five within-row spacing within the southeastern United States.

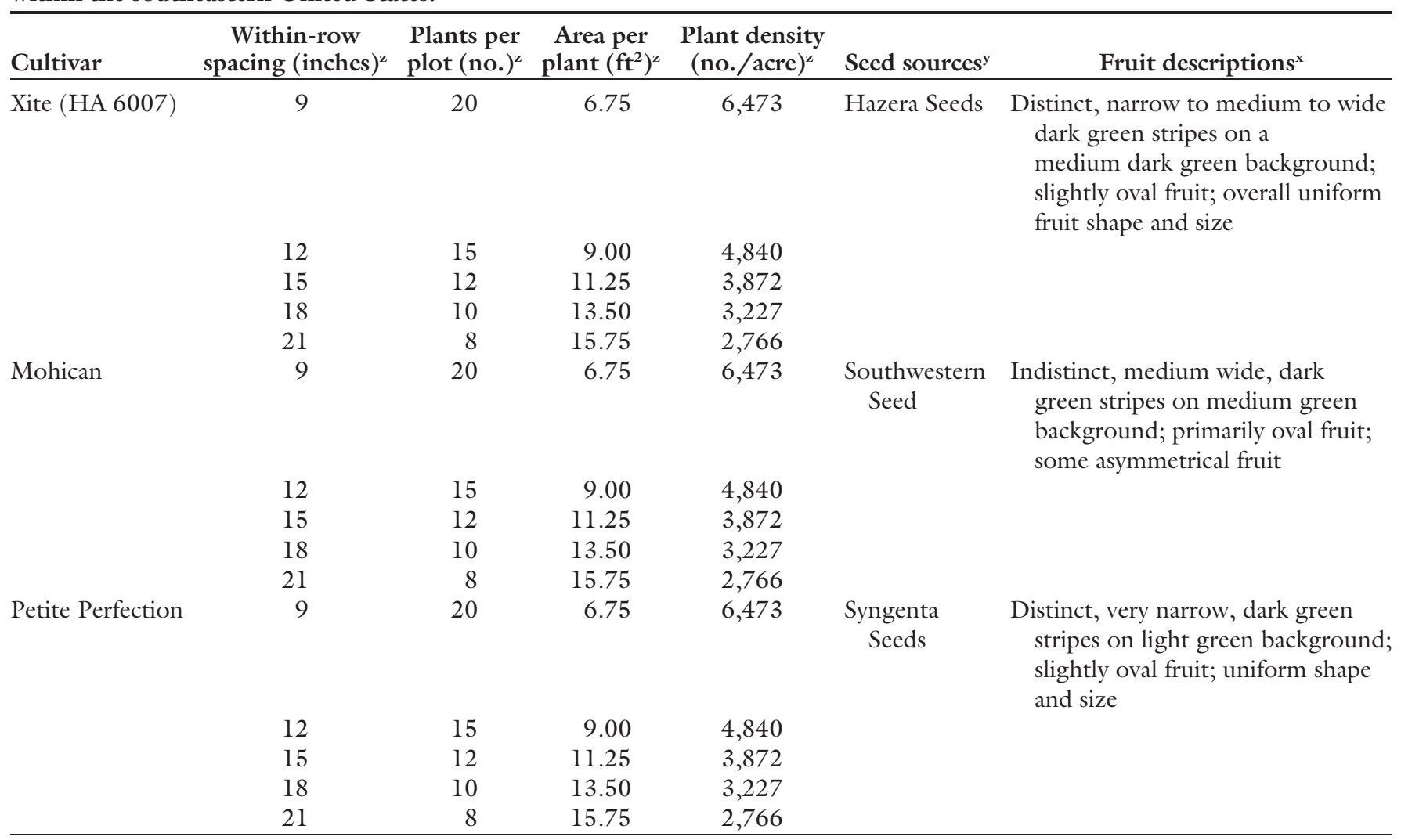

${ }^{\mathrm{z}} 1$ inch $=2.54 \mathrm{~cm}, \mathrm{l}$ plant per $15-\mathrm{ft}(4.6 \mathrm{~m})$ plot $=0.2187 \mathrm{plant} / \mathrm{m}, \mathrm{l} \mathrm{ft}{ }^{2}=0.0929 \mathrm{~m}^{2}, \mathrm{l}$ plant $/$ acre $=0.4047 \mathrm{plant} / \mathrm{ha}$.

'Hazera Seeds, El Segundo, CA; Southwestern Seed, Casa Grande, AZ; Syngenta Seeds, Boise, ID.

${ }^{x}$ Hassell et al., 2007. 
each watermelon, and total soluble solids were measured using a traditional hand held (Cole-Parmer, Vernon Hills, IL) or digital refractometer (Reichert Scientific Instruments, Buffalo, NY). Rind thickness was recorded to the nearest $1 / 8$ inch, on four regions of the fruit, starting at the stem end, and thereafter every $90^{\circ}$. The occurrence of hollow heart (Maynard and Hopkins, 1999), for each fruit, was obtained with length and width measures of the hollow area to the nearest $1 / 8$ inch. Fruit shape was obtained by measuring the length and width of five fruit. The length-to-width ratio was calculated, and a rating of 1 indicated the fruit was round, while a rating $>1$ indicated the fruit tended toward an oblong shape. Triploid watermelons are generally seedless but dark hard seedcoats have been reported to form within the flesh of the fruit (Maynard and Hopkins, 1999). These objectionable seedcoats are in part influenced by the environment (Maynard, 2001), but are influenced by other factors. The presence or absence of dark seedcoats in the plane of the cut mesocarp was recorded by using the following index: $0=$ no seedcoats, $1=<10$ seedcoats, $2=>10$ but $<50$ seedcoats, and $3=>50$ seedcoats. This is a rating that has been developed for hard seed evaluation. Most quality measures were taken at first harvest. Fruit were graded according to U.S. Department of Agriculture grading standards for all watermelons (USDA, 1978).

Data from all locations were combined and statistical analysis was conducted using SAS (version 8; SAS Institute, Cary, NC). The experimental design was a randomized complete block design consisting of four replications at each location. Analysis of variance was conducted for yields and quality data. Means were separated for cultivars using least significant differences (LSD) at the $1 \%$ and $5 \%$ levels of significance.

Kinston, NC. Seed were sown into LE 1803 transplant trays (Landmark Plastics, Akron, $\mathrm{OH}$ ) on 6 Apr. 2004. The planting medium used for transplants was Fafard 4P (Conrad Fafard, Agawam, MA). The transplants were grown for 6 weeks using the seedless watermelon transplant production guide recommendations (Hassell and Schultheis, 2002).
About 3 to 4 weeks after seeding, the plants were placed in a coldframe and hardened before being transplanted in the field on 13 May. The soil was a Norfolk sandy loam (fine, loamy siliceous thermic Typic Paleudults). Soil samples were taken in the fall, and based on those readings, the fertilizer program was determined by following the recommendations in the published standards for North Carolina (Sanders, 2004). In North Carolina, fertilizer was incorporated into the bed on 6 Apr. and the fumigant 1,3-dicloropropene/chloropicrin (Telone C-17; Dow AgroSciences, Indianapolis) was injected before laying black polyethylene plastic ( 1.25 mil thick, 60 inches wide; Reddick Fumigants, Williamston, NC) Ethalfluralin (Curbit; Platte Chemical, Fremont, NE) herbicide at $3 \mathrm{pt} /$ acre was applied between the plastic mulched beds for weed control on 20 Apr. At transplanting, a starter solution was applied using $20 \mathrm{~N}-$ $8.8 \mathrm{P}-16.6 \mathrm{~K}(0.5 \mathrm{lb} / 50$ gal water $)$ and diazinon (Diazinon 50W; Makhteshim Agan of North America, Raleigh, NC) insecticide at $1.0 \mathrm{oz}$ / 35 gal water for insect control. Trickle irrigation [ 8 mil thick, 12 -inch emitter spacing, $0.24 \mathrm{gal} / \mathrm{h}$ per emitter (T-tape; T-Systems International, San Diego)] was used to irrigate and fertilize over the growing season. Fertigation was initiated 2 weeks after planting on 17 May and was applied weekly until 2 Aug. Several pesticides were applied weekly to control insect and diseases according to the recommended published standards for North Carolina (Sanders, 2004). The weeds between plastic were controlled with a shielded sprayer with paraquat dichloride (Gramoxone; Syngenta Crop Protection, Greensboro, NC) on 22 May. Harvest one began 14 July, while the last harvest (the fourth) was 26 Aug.

Charleston, SC. Seeds were sown into transplant trays (TLC \#128; TLC Polyform, Atlanta) on 15 Mar. 2004 using Metro Mix 360 soilless mix (Scotts, Marysville, $\mathrm{OH}$ ). The transplants were grown for 6 weeks using the seedless watermelon transplant production guide recommendations (Hassell and Schultheis, 2002). The field experiments were conducted at the Clemson University Coastal Research and Education Center, Charleston, SC. The soil was
Yauhmal (Aquic Hapludults) fine loamy sand. Soil samples were taken in the fall, and based on those readings, the fertilizer program was determined by following the recommendations in the published standards for South Carolina (Sanders, 2004). In South Carolina, fertilizer was incorporated into the bed and fumigated with 1,3-dicloropropene/ chloropicrin (Telone C-17) before laying black polyethylene plastic (1.25 mil thick, 66 inches wide) on 10 Mar. Ethalfluralin and clomazone (Strategy; Loveland Products, Greeley, CO) herbicides were applied at 3 $\mathrm{pt} /$ acre between the plastic mulched beds for weed control on $20 \mathrm{Apr}$. At transplanting on 27 Apr., a starter solution was applied using $20 \mathrm{~N}-$ $8.8 \mathrm{P}-16.6 \mathrm{~K}(0.5 \mathrm{lb} / 50$ gal water $)$ and diazinon (Diazinon 50W) insecticide at $1.0 \mathrm{oz} / 35$ gal water for insect control. Trickle irrigation [8 mil thick, 12-inch emitter spacing, $0.24 \mathrm{gal} / \mathrm{h}$ per emitter (T-tape)] was used to irrigate and fertilize over the growing season. Fertigation was initiated 1 week after planting on 4 May and was applied weekly until 2 July. Fertigation rates and rate durations, along with several pesticides were applied weekly according to recommendations published for South Carolina (Sanders, 2004). Harvest began 20 June and ended 6 July.

Blackville, SC. The field experiment was conducted at the Clemson University Edisto Research and Education Center Blackville, SC. The watermelon beds were prepared and fertilizer was applied on 15 to 19 Mar. 2004. The soil was a Dothan loam sand (2-6\% slope; DaB series). Soil samples were taken in the fall, and based on those readings, the fertilizer program was determined by following the published procedures for South Carolina (Sanders, 2004). Fertilizer was incorporated into the soil on 16 Mar. On 17 Mar., beds were fumigated with methylbromide: chloropicrin, 67:33; Great Lakes Chemical, Lafayette, IN) at $23 \mathrm{lb} /$ $1000 \mathrm{ft}$ (linear) before black polyethylene plastic $(0.7$ mil thick, 60 inches wide; Sonoco, Hartsville, SC) application. Drip irrigation tubing [8 mil thick, 12-inch emitter spacing, $0.48 \mathrm{gal} / 100 \mathrm{ft}$ (linear) per hour (T-tape)] was applied at this time. The planting medium used was Metro Mix 360 (Scotts). Seeded trays 
were kept in a germination room at $90{ }^{\circ} \mathrm{F}$ for $48 \mathrm{~h}$ and were then moved to the greenhouse. Greenhouse temperatures were set for $65^{\circ} \mathrm{F}$ at night and $75^{\circ} \mathrm{F}$ during the day. On 22 Apr. (25 d after planting), the seedless watermelon transplants were moved to wire racks at the field $2 \mathrm{~d}$ before being transplanted in the field on 24 Apr. Drip irrigation was initiated at planting, for two cycles per day. Daily fertigation through the drip system was begun on 2 May. Fertigation rates and durations were applied according to recommendations published for South Carolina (Sanders, 2004). Ethalfuralin and clomazone (Strategy) was applied at $3 \mathrm{pt} /$ acre on 11 May. Several pesticides were applied weekly to control insects and diseases according to the published standards for South Carolina (Sanders, 2004). The watermelons were harvested three times: 28 June, 6 July, and 13 July.

Quincy, FL. Seeds were planted in a peat-lite growing mix in expanded polystyrene flats of inverted pyramid design [Todd Planter flats; Speedling, Sun City, FL) $(1.5 \times 1.5 \times$ 2.5-inch cells)] on 23 Feb. 2004. Soil type was an Orangeburg loamy fine sand (fine loamy, siliceous, thermic Typic Paleudults). Soil samples were taken in the fall, and based on those readings, the fertilizer program was determined by following the published procedures for Florida (Olson and Simonne, 2004). Fertilizer was broadcast over the designated area before beds were formed. Beds were pressed, fumigated with methyl bromide/chloropicrin $(67: 33)$ at 350 $\mathrm{lb} /$ acre (treated), and drip tape [ 10 mil thick, 12-inch emitter spacing, $0.5 \mathrm{gal} / 100 \mathrm{ft}$ (linear) per minute (Twin Wall IV, Chapin Watermatics, Watertown, NY)] was applied along with the black polyethylene mulch (1.25 mil thick, 60 inches wide; Pliant, Bloomington, IN). The final beds were 36 inches wide and 6 inches high. The transplants were set on 25 Mar. Weed control in row middles was by cultivation and applications of paraquat dichloride (Gramoxone) and Ethalfluralin (Curbit) herbicides. Pesticides were applied as needed using the Vegetable Production Handbook for Florida (Olson and Simonne, 2004). Watermelons were harvested on 21 and 28 June and 8 July. Quality measurements were taken from fruit harvested on 21 June.

\section{Results}

Total AND PERCENTAge OF MARKETABLE YIELDS. There was a significant cultivar by location interaction, suggesting that the three cultivars responded differently at each of the four locations (Table 2). For total fruit weight and fruit number, 'Xite' was the highest yielding cultivar in the Quincy location, however, at the Charleston site it, was the lowest yielding cultivar (Table 3 ). 'Petite Perfection' was among the highest yielding at all locations except Quincy, where it was the lowest yielding cultivar. As with total yields, the percentage of marketable fruit was similar for some cultivars across locations. Individual fruit were considered marketable if they were between 3 and 9 lb. 'Petite Perfection' produced the highest percentage of marketable fruit at three of the four locations. The exception was the Quincy site where 'Xite' had the highest percentage of marketable fruit. Within-row plant populations affected total marketable yield, both for fruit weight and number per plot, regardless of cultivar and location (Table 2). As the within-row plant population increased from 8 plants per plot (21 inches in-row spacing) to 12 plants per plot (15 inches inrow spacing), total miniwatermelon marketable fruit yields increased in total fruit number as well as total weight (Table 4). After that point, no significant yield increase was seen as plant populations increased from 15 to 20 plants per plot.

Percentage of Distribution OF MELON SIZE. There was a significant cultivar by location interaction, indicating that size distribution among some cultivars was affected by the growing environment (Table $2)$. At the Quincy site, there were significant percentages of melons of all three cultivars in the less than 3-lb class (cull melons) (Table 3 ). 'Petite Perfection' had the most undersized cull melons at $32 \%$. The other three sites (Charleston, Edisto, and Kinston) produced fruit that had minimal numbers is this category. 'Petite Perfection' produced the greater percentage of small marketable fruit $(3.1-5.0 \mathrm{lb})$ in

Table 2. Percentages of the treatment sum of squares of the model for yield and quality variables partitioned into main and interaction effects for three miniwatermelon cultivars at increasing within-row plant distances ${ }^{\mathrm{z}}$ grown in four locations within the southeastern United States.

\begin{tabular}{|c|c|c|c|c|c|c|c|c|}
\hline \multirow{2}{*}{$\begin{array}{l}\text { Source of } \\
\text { variation }\end{array}$} & \multicolumn{3}{|c|}{ Total miniwatermelon marketable yields } & \multicolumn{5}{|c|}{ Distribution of melons among wt classes $(\%)^{\mathrm{w}}$} \\
\hline & $(\mathrm{lb} / \text { plot })^{\mathrm{y}}$ & $(\text { no./plot })^{\mathrm{y}}$ & Marketable $\%^{\mathrm{x}}$ & $\leq 3.0 \mathrm{lb}^{\mathrm{y}}$ & $3.1-5.0 \mathrm{lb}$ & $5.1-7.0 \mathrm{lb}$ & $7.1-9.0 \mathrm{lb}$ & $\geq 9.1 \mathrm{lb}$ \\
\hline Replication & 0 & 0 & 1 & 0 & 2 & 3 & 2 & 2 \\
\hline Location $(\mathrm{L})$ & $46 * * v$ & $48 * *$ & $14^{* *}$ & $55^{* *}$ & 9 ** & 15 ** & 9 ** & $8 * *$ \\
\hline Cultivar (C) & $6 * *$ & $10 * *$ & $16 * *$ & 9 ** & $56 * *$ & $4^{*}$ & $37 * *$ & $45^{* *}$ \\
\hline $\mathrm{L} \times \mathrm{C}$ & $12 * *$ & 9 ** & $18 * *$ & 12 ** & $3^{*}$ & 12 ** & $6^{* *}$ & $8 * *$ \\
\hline Population $(\mathrm{P})$ & $3^{*}$ & $3^{*}$ & 2 & 0 & 2 & 0 & 1 & 1 \\
\hline $\mathrm{L} \times \mathrm{C} \times \mathrm{P}$ & 4 & 2 & 8 & 5 & 4 & 11 & 5 & 4 \\
\hline Error & 25 & 25 & 37 & 17 & 21 & 45 & 34 & 26 \\
\hline
\end{tabular}

${ }^{\mathrm{z}}$ Evaluated within-row distance of $8,10,12,15$, and 20 plants per 15 -ft $(4.6 \mathrm{~m})$ plot are equivalent to $21,18,15,12$, and 9 inches between plants, respectively; 1 inch $=$ $2.54 \mathrm{~cm}$.

${ }^{\mathrm{y}} \mathrm{l} \mathrm{lb}=0.4536 \mathrm{~kg}, 1$ melon per $15-\mathrm{ft}$ plot $=0.2187 \mathrm{melon} / \mathrm{m}$.

${ }^{x}$ Percentage of total (cull and marketable number/plot) yield. Analysis was performed after arcsin transformation of the percentage data.

"Fruit were divided into five categories based on weight ranges from $\leq 3.0 \mathrm{lb}$ (culls), 3.1 to $9.0 \mathrm{lb}$ (marketable), and $\geq 9.1 \mathrm{lb}$ (culls). Analysis was performed after arcsin transformation of the percentage data.

${ }^{v *},{ }^{*} \mathrm{~F}$ values significant at $P=0.05$ and 0.01 , respectively. 
Table 3. Miniwatermelon yield of three cultivars planted in four diverse locations (pooled over five plant populations) within the southeastern United States.

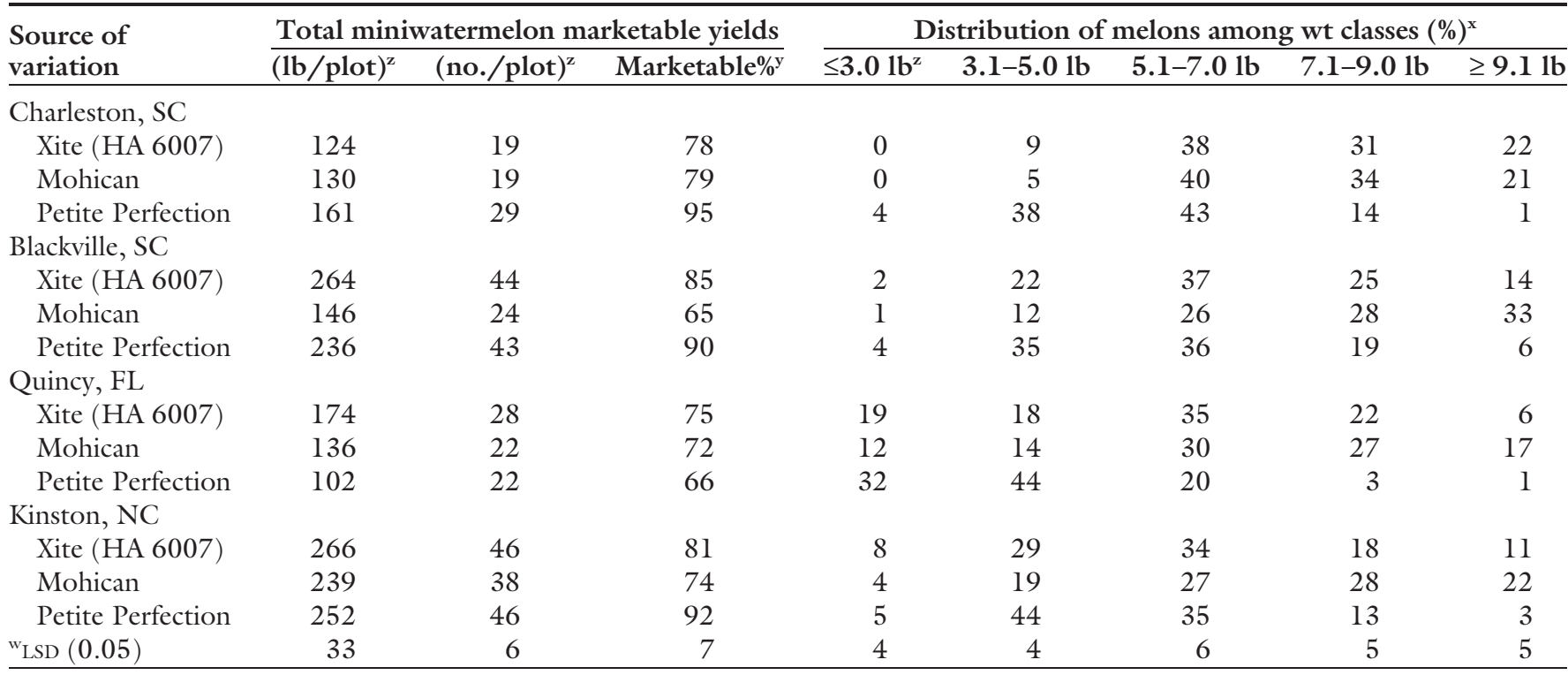

${ }^{\mathrm{z}} 1 \mathrm{lb}=0.4536 \mathrm{~kg}, \mathrm{l}$ melon per $15-\mathrm{ft}(4.6 \mathrm{~m})$ plot $=0.2187 \mathrm{melon} / \mathrm{m}$.

Percentage of total (cull and marketable number/plot) yield. Analysis was performed after arcsin transformation of the percentage data.

${ }^{x}$ Fruit were divided into five categories based on weight ranges from $\leq 3.0 \mathrm{lb}$ (culls), 3.1 to $9.0 \mathrm{lb}$ (marketable), and $\geq 9.1 \mathrm{lb}$ (culls). Analysis was performed after arcsin transformation of the percentage data.

wLeast significant difference values $(\alpha=0.05)$ for pounds per plot, number per plot, percentage marketable, and distribution of watermelon fruit at each of the five classes, respectively.

Table 4. Main effects of plant population (pooled over four locations and three cultivars) on yield of miniwatermelons within the southeastern United States.

\begin{tabular}{lcc}
\hline $\begin{array}{l}\text { Plant population } \\
\text { (no./plot) }\end{array}$ & \multicolumn{2}{c}{ Total miniwatermelon marketable yields } \\
\cline { 2 - 3 }$(\text { (lb/plot })^{\mathrm{y}}$ & ${\text { (no./plot })^{\mathrm{y}}}^{\mathrm{z}}$ & $28 \mathrm{~b}$ \\
8 & $170 \mathrm{c}^{\mathrm{x}}$ & $30 \mathrm{~b}$ \\
10 & $177 \mathrm{bc}$ & $32 \mathrm{ab}$ \\
12 & $184 \mathrm{a}-\mathrm{c}$ & $34 \mathrm{a}$ \\
15 & $203 \mathrm{a}$ & $34 \mathrm{a}$ \\
20 & $196 \mathrm{ab}$ & \\
\hline
\end{tabular}

${ }^{2}$ Evaluated within-row distances of $8,10,12,15$, and 20 plants per 15 - $\mathrm{ft}(4.6 \mathrm{~m})$ plot are equivalent to $21,18,15$, 12 , and 9 inches between plants, respectively; 1 plant per $15-\mathrm{ft}$ plot $=0.2187$ plant $/ \mathrm{m}, 1$ inch $=2.54 \mathrm{~cm}$.

${ }^{\mathrm{y}} \mathrm{l} \mathrm{lb}=0.4536 \mathrm{~kg}, 1$ melon per 15 -ft plot $=0.2187 \mathrm{melon} / \mathrm{m}$.

${ }^{x}$ Means within columns followed by the same lowercase letter are not significant at $P \leq 0.05$.

all locations and 'Mohican' the fewest in all locations. Within the medium size marketable class (5.1-7.0 lb), location had more of an effect on percentage of fruit produced than cultivar (Table 2). Cultivar percentages varied considerably across growing sites (Table 3 ). Within the large-size marketable class (7.1-9.0 lb), 'Mohican' consistently produced a greater percentage of large marketable fruit at all locations, and 'Petite Perfection' the lowest in all locations. In the greater than 9-1b class (oversize cull melons), 'Mohican' produced a greater percentage of fruit than the two other cultivars in three of the four locations. At the Charleston site, 'Xite' and 'Mohican' produced an equal percentage of over size cull fruit. 'Petite Perfection' had the least percentage of oversized cull fruit at all locations.

Quality Variables. There was a significant cultivar by location interaction for the percentage of soluble solids and the rind thickness measurements, suggesting that some cultivars responded differently at each of the four locations (Table 5 ). 'Petite Perfection' produced the highest soluble solid reading at all locations, but this was significant only at the Blackville site when compared with 'Mohican' and the Kinston site when compared with 'Xite' (Table 6). Quality effects were more apparent with 'Mohican' and 'Xite', as they were more responsive to location. Higher soluble solid content readings were obtained, regardless of cultivar, at Quincy and Kinston, the exception being 'Xite' at Kinston when compared with the two South Carolina locations in which no statistical differences were measured. 'Petite Perfection' consistently had the thinnest rind compared with 'Xite' and 'Mohican' (Table 6), regardless of location or rind sampling site. Rind thickness, regardless of sample site, was greater at the South Carolina sites than the Florida or North Carolina locations. There was more of a location effect on the presence of dark seedcoats and a cultivar effect on the shape of the fruit (Table 5). 'Petite Perfection' had fewer dark seedcoats in the fruit than the other two cultivars (Table 7). The fruit of 'Petite Perfection' tended to be more round, with 'Xite' being slightly more oblong. The two South Carolina locations (Charleston and Blackville) recorded the fewest melons with the presence of dark seedcoats within the fruit than the other two sites (Table 8). The Kinston location produced a significantly higher presence of dark seedcoats within the fruit. The Blackville location was the only site to record all round fruit compared with the other locations that had slightly oblong fruit. 
Table 5. Percentages of the treatment sum of squares of the model for quality variables partitioned into main and interaction effects for three miniwatermelon cultivars grown at increasing within-row plant populations ${ }^{\mathrm{z}}$ in four southeastern locations within the United States.

\begin{tabular}{|c|c|c|c|c|c|c|c|}
\hline \multirow[b]{2}{*}{$\begin{array}{l}\text { Source of } \\
\text { variation }\end{array}$} & \multirow[b]{2}{*}{$\operatorname{SSC}(\%)^{\mathrm{y}}$} & \multirow[b]{2}{*}{$\begin{array}{l}\text { Seed index } \\
(0-3 \text { scale })^{x}\end{array}$} & \multicolumn{4}{|c|}{ Rind thickness (inches) ${ }^{\mathrm{w}}$} & \multirow{2}{*}{$\begin{array}{c}\text { Fruit shape } \\
\text { index } \\
(1-2 \text { scale })^{v}\end{array}$} \\
\hline & & & $\begin{array}{c}\text { Stem } \\
\text { end }\end{array}$ & $\begin{array}{c}\text { Blossom } \\
\text { end }\end{array}$ & Top & Bottom & \\
\hline Rep. & 2 & 3 & 0 & 1 & 1 & 0 & 2 \\
\hline Location (L) & $71 * *$ & $18 * *$ & $18 * *$ & $12 * *$ & $9 * *$ & $7 * *$ & $6^{* *}$ \\
\hline Cultivar (C) & $2 * *$ & $4^{* *}$ & $60 * *$ & $64 * *$ & $74^{* *}$ & $68 * *$ & $18 * *$ \\
\hline $\mathrm{L} \times \mathrm{C}$ & $2 * *$ & 5 & $3 * *$ & $2 * *$ & 2 ** & $2 * *$ & 1 \\
\hline Population (P) & 1 & 1 & 1 & 1 & 1 & 0 & 2 \\
\hline $\mathrm{L} \times \mathrm{P}$ & 1 & 4 & 1 & 2 & 2 & 1 & 1 \\
\hline $\mathrm{C} \times \mathrm{P}$ & 1 & 4 & 1 & 1 & 1 & 1 & 2 \\
\hline $\mathrm{L} \times \mathrm{C} \times \mathrm{P}$ & 3 & 13 & 1 & 2 & 2 & 1 & 6 \\
\hline Error & 17 & 48 & 15 & 15 & 8 & 20 & 62 \\
\hline
\end{tabular}

${ }^{z}$ Evaluated within-row distance of $8,10,12,15$, and 20 plants per 15 -ft ( $4.6 \mathrm{~m}$ ) plot are equivalent to $21,18,15$, 12 , and 9 inches between plants, respectively; 1 plant per 15 - $\mathrm{ft}$ plot $=0.2187$ plant $/ \mathrm{m}, \mathrm{l}$ inch $=2.54 \mathrm{~cm}$.

y Soluble solids concentration (SSC) measured with refractometer from a sample taken between blossom and stem end.

${ }^{x}$ Each cut melon was rated for seediness using the following scale: $0=$ no seeds; $1=\geq 1$ but $\leq 10$ seeds; $2=>10$ but $\leq 50$ seeds; $3=>50$ seeds.

"Five randomly selected fruit were cut from blossom end to stem end before measurements were taken.

"Each melon was rated according to shape: 1 = round and 2 = oblong.

${ }^{\star *}$ F values significant at $P=0.01$

Table 6. Miniwatermelon quality of five randomly sampled marketable melons (pooled over five plant populations and four locations) within the southeastern United States.

\begin{tabular}{lccccc}
\hline & & \multicolumn{5}{c}{ Rind thickness (inches) $^{\mathrm{y}}$} \\
\cline { 3 - 6 } Cultivar & SSC (\%) & Stem end & Blossom end & Top & Bottom \\
\hline Charleston, SC & & & & & \\
Xite (HA 6007) & 10.9 & 0.72 & 0.59 & 0.66 & 0.64 \\
Mohican & 11.0 & 0.71 & 0.57 & 0.62 & 0.62 \\
Petite Perfection & 11.2 & 0.35 & 0.28 & 0.35 & 0.31 \\
Blackville, SC & & & & & \\
Xite (HA 6007) & 10.7 & 0.68 & 0.71 & 0.71 & 0.70 \\
Mohican & 9.9 & 0.71 & 0.70 & 0.71 & 0.75 \\
Petite Perfection & 11.1 & 0.34 & 0.32 & 0.32 & 0.34 \\
Quincy, FL & & & & & \\
Xite (HA 6007) & 13.4 & 0.47 & 0.50 & 0.55 & 0.58 \\
Mohican & 13.4 & 0.50 & 0.51 & 0.54 & 0.56 \\
Petite Perfection & 13.6 & 0.22 & 0.22 & 0.22 & 0.23 \\
Kinston, NC & & & & & \\
Xite (HA 6007) & 11.2 & 0.57 & 0.52 & 0.59 & 0.60 \\
Mohican & 11.9 & 0.61 & 0.52 & 0.61 & 0.61 \\
Petite Perfection & 12.0 & 0.30 & 0.29 & 0.31 & 0.33 \\
x & 0.5 & 0.08 & 0.07 & 0.05 & 0.08 \\
\hline
\end{tabular}

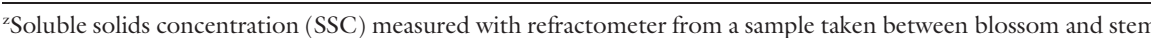
end.

${ }^{y}$ Five randomly selected fruit were cut from blossom end to stem end before measurements were taken; 1 inch = $2.54 \mathrm{~cm}$.

${ }^{x}$ Least significant difference values $(\alpha=0.05)$ for soluble solids and rind thickness at each of the four positions, respectively.

\section{Discussion}

Increased production efficiencies, whether using season extenders (Arancibia and Motsenbocker, 2008; Wells and Loy, 1985), optimizing fertilizer management (Brinen et al., 1979; Dweikat and Kostewicz, 1989; Roberts et al., 1999; Srinivas et al., et al., 1999a, 1999b; Motsenbocker and Arancibia, 2002; NeSmith, 1993; Sanders et al., 1999; Srinivas et al., 1989), are a necessity when the profit margin or bottom line is challenged by one or more of these or other factors. In this study, we evaluated the effects of using various miniwatermelon cultivars at different planting densities and how this affected yield and quality of the fruit across different locations.

Cultivar and environment (location) played a significant role in yield and quality of the fruit (Table 2). This is not surprising as certain watermelon cultivars often produce consistently better from season to season (Cushman et al., 2003). In this study, 'Petite Perfection' produced the highest number of marketable fruit compared with 'Xite' and 'Mohican'. A significantly lower percentage of oversized culls were produced by 'Petite Perfection' compared with the other two cultivars evaluated. Environment or location plays a crucial role in how cultivars respond to seasonal differences in soil type, moisture, temperature, etc., as all can affect the yield and quality response of the cultivar (Arancibia and Motsenbocker, 2008; Taber, 1993). Specifically, when planting density increased with watermelon, Duthie et al. (1999a) reported that in four experiments, there was no effect on fruit size, but in three experiments, there was a curvilinear decrease. Our results indicated that fruit size was unaffected by increasing plant density.

Our results across locations differed as well with respect to cultivar response relative to each other and varied in yield and quality across locations. For example, the specific reasons as to why in one location there were more dark, hard seeds in one cultivar than in another is not clear. Yields were generally higher in the Kinston location and this was likely due to the higher number of harvests (four) compared with the other locations (three).

Planting density or in-row spacing can alter production, both yields and fruit size (Brinen et al., 1979; Duthie et al., 1999a, 1999b; NeSmith, 1993; Sanders et al., 1999). Results from earlier watermelon studies suggest that fruit size declines quickly with larger-fruited watermelon cultivars such as Prince Charles and Royal 
Table 7. Main effects of cultivar (pooled over five populations and four locations) of five random samples of marketable miniwatermelons ${ }^{\mathrm{z}}$ per treatment on seed index and fruit shape index.

\begin{tabular}{lcc}
\hline Cultivar & Seed index $\left(0-3\right.$ scale $^{\mathrm{y}}$ & Fruit shape ratio $^{\mathrm{x}}$ \\
\hline Xite (HA 6007) & $0.21 \mathrm{a}^{\mathrm{w}}$ & $1.13 \mathrm{a}$ \\
Mohican & $0.20 \mathrm{a}$ & $1.10 \mathrm{ab}$ \\
Petite Perfection & $0.11 \mathrm{~b}$ & $1.05 \mathrm{~b}$ \\
\hline
\end{tabular}

${ }^{\mathrm{z}}$ Each fruit was cut from blossom end to stem end before measurements were taken.

${ }^{y}$ Each cut melon was rated for seediness using the following scale: $0=$ no seeds; $1=\geq 1$ but $\leq 10$ seeds; $2=>10$ but $\leq 50$ seeds; $3=>50$ seeds

${ }^{\times}$Ratio of $\mathrm{l}=$ round and $>1$ fruit tends toward oblong.

${ }^{w}$ Means within columns followed by the same lowercase letter are not significant at the $P \leq 0.05$.

Table 8. Main effects of location (pooled over five populations and three cultivars) of five random samples of marketable miniwatermelons ${ }^{\mathrm{z}}$ per treatment on seed index and fruit shape ratio.

\begin{tabular}{lcc}
\hline Location & Seed index $(\mathbf{0}-\mathbf{3} \text { scale })^{\mathrm{y}}$ & Fruit shape ratio $^{\mathrm{x}}$ \\
\hline Charleston, SC & $0.11 \mathrm{c}^{\mathrm{w}}$ & $1.12 \mathrm{a}$ \\
Blackville SC & $0.07 \mathrm{c}$ & $1.00 \mathrm{~b}$ \\
Quincy, FL & $0.20 \mathrm{~b}$ & $1.12 \mathrm{a}$ \\
Kinston, NC & $0.31 \mathrm{a}$ & $1.12 \mathrm{a}$ \\
\hline
\end{tabular}

${ }^{2}$ Each fruit was cut from blossom end to stem end before measurements were taken.

Each cut melon was rated for seediness using the following scale: $0=$ no seeds; $1=\geq 1$ but $\leq 10$ seeds; $2=>10$ but $\leq 50$ seeds; $3=>50$ seeds.

${ }^{\mathrm{x}}$ Ratio of $\mathrm{l}=$ round and $>\mathrm{l}$ fruit tends toward oblong.

${ }^{w}$ Means within columns followed by the same lowercase letter.

Jubilee (Sanders et al., 1999), Crimson Sweet and Starbrite (NeSmith, 1993), and Charleston Gray (Brinen et al., 1979) as plant populations increased. The fruit size of miniwatermelon cultivars at the densities used in our studies was not significantly altered (Table 2). This is important because only slight variations in miniwatermelon fruit size $(1 \mathrm{lb})$ can render the fruit as unmarketable because it might not fit into standard size boxes designed for marketing of mini fruit.

Although in-row spacing did not alter fruit size, it did affect yields. Yields peaked when in-row spacing was reduced from 21 to 15 inches; however, no additional yield benefit was obtained at the closer in-row spacings of 9 and 12 inches. The additional cost of $50 \%$ more plants would need to be overcome by the additional $12 \%$ yield increase of fruit produced per area found in these studies. The market price of the fruit fluctuates from year to year, depending on market supply and demand, making that discussion a difficult one. This agrees with Weiner (1990) and Willey and Heath (1969), who stated that increased plant population densities result in increased yields until a threshold density is reached, at which time yields level off or decline.
Based on these studies, the most consistent high marketable-yielding cultivar was Petite Perfection, with all cultivars reaching their yield potential at in-row spacing of 15 inches. Future studies should evaluate the effects of altering planting densities by varying between-row spacing to determine how this affects yields, fruit size, and quality.

\section{Literature cited}

Arancibia, R.A. and C.E. Motsenbocker. 2008. Differential watermelon fruit size distribution in response to plastic mulch and spunbonded polyester rowcover. HortTechnology 18:45-52.

Barboza, D. 2003. Fresh from the consumer polls, pint-size watermelons. 10 July 2005. <http://www.nytimes.com/ 2003/06/15/business/15MELO.html? pagewanted $=$ landei $=500>$.

Brinen, G.H., S.J. Locascio, and G.W. Elmstrom. 1979. Plant and row spacing, mulch, and fertilization rate effects on watermelon production. J. Amer. Soc. Hort. Sci. 104:724-726.

Cantliffe, D.J. and S.C. Phatak. 1975. Plant population studies with pickling cucumbers grown for once-over harvest. J. Amer. Soc. Hort. Sci. 100:464-466.

Cushman, K.E., R.G. Snyder, D.H. Nagel, and P.D. Gerard. 2003. Yield and quality of triploid watermelon culti- vars and experimental hybrids grown in Mississippi. HortTechnology 13:375380 .

Duthie, J.A., B.W. Roberts, J.V. Edelson, and J.W. Schrefler. 1999a. Plant densitydependent variation in marketable yield, fruit biomass, and marketable fraction in watermelon. Crop Sci. 39:406-412.

Duthie, J.A., B.W. Roberts, J.V. Edelson, and J.W. Schrefler. 1999b. Plant densitydependent variation in density, frequency, and size of watermelon fruits. Crop Sci. 39:412-417.

Dweikat, I.M. and S.R. Kostewicz. 1989. Row arrangement, plant spacing, and nitrogen rate effects on zucchini squash yield. HortScience 24:86-88.

Halsey, L.H. 1959. Watermelon spacing and fertilization. Proc. Florida State Hort. Soc. 73:131-135.

Hassell, R.L. and J.R. Schultheis. 2002. Seedless watermelon transplant production guide. 1 Feb. 2004. <www.clemson. edu/psapublishing/ppt_files / Seedlesswatermelon.ppt $>$.

Hassell, R.L., J.R. Schultheis, W.R. Jester, S.M. Olson, D.N. Maynard, and G.A. Miller. 2007. Yield and quality of mini triploid watermelon cultivars in diverse locations in the Southeast. HortTechnology 17:608-617.

Hoyt, G.D., D.W. Monks, and T.J. Monaco. 1994. Conservation tillage for vegetable production. HortTechnology 4:129-135.

Knavel, D.E. 1991. Productivity and growth of short-internode muskmelon plants at various spacings or densities. J. Amer. Soc. Hort. Sci. 116:926-929.

Maynard, D.N. 2001. Watermelons characteristics, production and marketing. ASHS Hort. Production Ser., ASHS Press, Alexandria, VA.

Maynard, D.N. and D.L. Hopkins. 1999. Watermelon fruit disorders. HortTechnology 9:155-161.

Maynard, D.N. and G.W. Elmstrom. 1992. Triploid watermelon production practices and varieties. Acta Hort. 318:169-173.

Motsenbocker, C.E. and R.A. Arancibia. 2002. In-row spacing influences triploid watermelon yields and crop value. HortTechnology 12:437-440.

NeSmith, D.S. 1993. Plant spacing influences watermelon yield and yield components. HortScience 28:885-887.

Olson, S.M. and E. Simonne. 2004. Vegetable production handbook for Florida. Vance Publishing, Lenexa, KS. 
Roberts, W., J. Duthie, J. Edleson, B. Cartwright, J. Shrefler, and N. Roe. 1999. Limitations and possibilities for some conservation tillage systems with vegetable crops in the southern plains of the United States. HortTechnology 9:359-365.

Sanders, D.C. (ed.). 2004. Vegetable crop guidelines for the southeastern U.S. 2004-2005. North Carolina Vegetable Growers Assn., Helena Chemical Co., Memphis, TN.

Sanders, D.C., J.D. Cure, and J.R. Schultheis. 1999. Yield response of watermelon to planting density, planting pattern, and polyethylene mulch. HortScience 34:1221-1223.

Schultheis, J.R., S.A. Walters, D.E. Adams, and E.A. Estes. 1999. In-row plant spacing and date of harvest of 'Beauregard' sweetpotato affect yield and return on investment. HortScience 34: 1229-1233.
Srinivas, K., D.M. Hegde, and G.V. Havanagi. 1989. Effect of nitrogen and plant population on yield, quality, nutrient uptake, and water use of watermelon (Citrullus lanatus Matsum et Nakai) under drip and furrow irrigation. Gartenbauwissenshaft 53S:220-223.

Stang, J.R., H.J. Mack, and K.E. Rowe. 1979. Quantitative relation of bush snap beans (Phaseolus vulgaris L.) yields to plant population density. J. Amer. Soc. Hort. Sci. 104:873-875.

Stoffella, P.J. and H.H. Bryan. 1988. Plant population influences growth and yields of bell pepper. J. Amer. Soc. Hort. Sci. 113:835-839.

Stoffella, P.J., S.J. Locascio, P.H. Everett, T.K. Howe, J.W. Scott, and S.M. Olson. 1988. Yields of tomato cultivars differing in shoot growth at several plant populations and locations. HortScience 23:991993.
Taber, H.G. 1993. Early muskmelon production with wavelength selective and clear plastic mulches. Hort Technology 3:78-80.

U.S. Department of Agriculture. 1978. United States standards for grades of watermelon. U.S. Dept. Agr., Agr. Mktg. Serv., Washington, DC.

Weiner, J. 1990. Plant population ecology in agriculture, p. 235-262. In: C.R. Carroll, J.H. Vandermeer, and P.M. Rosset (eds.). Agroecology, McGrawHill, New York.

Wells, O.S. and J.B. Loy. 1985. Intensive vegetable production with rowcovers. HortScience 20:822-826.

Willey, R.W. and S.B. Heath. 1969. The quantitative relationships between plant populations and crop yield. Adv. Agron. 21:281-321. 